Beata Stefaniak-Maślanka

\title{
Baśń, storytelling i popkultura
}

\section{Współczesna baśń w odcinkach}

Kaja Klimek w artykule pt. Baśnie księżniczki popkultury opublikowanym w dwutygodniku „Film” pisze o zjawisku widocznym w kulturze w ostatnich latach: baśń, a więc historia, której sercem jest - według Matsa Rehnmana - ,intensywne doświadczenie egzystencji” [Rehnman 2011], jest od pewnego czasu modnym językiem popkultury, choć „nie jest też tak, że oto nagle, po wielu latach nieobecności, na ekrany powracają opowieści zainspirowane baśniami” [Klimek 2011]. Ocena nowych odczytań, przeróbek i aktualizacji baśni jest jednak niejednoznaczna. Według niektórych badaczy kultura masowa skazuje baśń na banicję i tworząc nowe wersje znanych fabul, nierzadko popada we wtórny infantylizm [np. Majkowski 2011; Franczak 2011], według innych współczesne baśnie nadal mogą być aktualne jako narracje o życiu i rzeczywistości [np. Araszkiewicz, Bratkowska 2005].

Niniejszy artykuł koncentruje się na dwóch serialach wpisujących się w formulę fantasy, wyemitowanych równolegle w $2011 \mathrm{r}$. Once upon a time i Grimm. Ich twórcy nie tyle wykorzystali schematy baśniowe, które zyskały już rangę mitów popkulturowych (na przykład historia szarej myszki wybranej przez księcia, jak Tatiana Cichocka i Katarzyna Miller określity formułę Kopciuszka fundującą komedie romantyczne i harlekiny) [Miller, Cichocka 2009], ile przenieśli do współczesności konkretne postaci i ich historie i wymieszali je ze sobą. Baśnie tworzą w obu produkcjach rzeczywistość, która się wydarzyła, czego konsekwencją jest kształt współczesności. Wydaje się, że można w nich widzieć coś więcej niż przejaw tendencji do powtarzania i przetwarzania chwytliwych motywów i tematów jako pustych znaków. Sprzyja temu 
zrezygnowanie z zamkniętej formuły filmowej na rzecz otwartej serii epizodów, a także próba nawiązywania do sensów psychologicznych baśni czy konfrontacji z baśniowymi stereotypami widoczna w obydwu projektach.

\section{Grimm, czyli indywiduacja a zwierzę na wolności}

Grimm jest historią policjanta, który odkrywa, że należy do starożytnego rodu Grimmów od wieków walczących z potworami. Bohater, rozwiązując kryminalne zagadki, zaczyna dostrzegać to, czego nie widzą inni - zwierzęcą naturę osób, które spotyka. Jego losy zostają wpisane w dzieje świata: w toku opowieści słyszymy o politycznej walce, działalności ruchu oporu, a nawet zyskujemy interpretację wydarzeń, które doprowadziły do wybuchu II wojny światowej. W epizodzie opartym na baśni Złodziej nad złodziejami i luźno nawiązującym do trylogii Tolkiena Hitler zostaje przedstawiony jako człowiek-wilk czerpiący moc z monet, które decydowały o losach świata od starożytności.

Grimm przejmuje z baśni przede wszystkim postaci potworów, które zostają poddane indywidualizacji. Wartość poznawcza i rozrywkowa kolejnych epizodów zasadza się na tym, że widz rozpoznaje w zbrodniach, o których słyszy w mediach, przetworzenia historii baśniowych. Okazuje się, że porywacz pedofil ma naturę wilka - kuszą go dziewczynki w czerwieni. Seryjny gwałciciel-uwodziciel to wcielenie Sinobrodego (człowieka-kozła), któremu, zgodnie z interpretacją Clarissy Pinkoli Estes, naiwne i nieszczęśliwe kobiety pozwalają się uwieść w nadziei łatwej rozkoszy [Pinkola Estes 2001: 47-59]. Z kolei hedonistyczny styl życia młodzieży znajduje analogię w baśni o Złotowłosej, która włamuje się do konserwatywnej rodziny niedźwiedzi.

Problemy natury kryminalnej (zabójstwa, uzależnienie od narkotyków, handel organami itd.) łączą się w opowieści z odwiecznymi trudnościami psychologicznymi. Dobrym przykładem jest nawiązująca do baśni Biały wąż i powieści Johna Steinbecka Myszy i ludzie historia toksycznego związku syna z ojcem, który nie pozwolił synowi dorosnąć, bo nie dał mu wiary w to, że jest kimś wartościowym. Taka wiara, zdaniem Brunona Bettelheima, jest konieczna dla prawidłowego roz- 
woju człowieka i kształtuje się od początku życia [Bettelheim 2010]. Wyniesione z domu poczucie „bycia nikim” okazuje się wewnętrznym potworem myszy-człowieka Martina na równi z uwewnętrznionym obrazem złego i potężnego ojca. Śmierć ojca tylko pozornie staje się wyzwoleniem. Złe relacje i zaburzony rozwój doprowadziły bowiem Martina do stanu, w którym rzeczywistość widzi jako złą i prześladowczą. Wyraźnie obrazują to sceny, w których wszyscy dominujący czy agresywni mężczyźni (łącznie z nim samym) przybierają oblicze zmarłego ojca, oraz następująca rozmowa:

- Znaleźliśmy Twojego ojca. Wiemy, że jest martwy.

- Nie, nie jest. Był, ale już nie jest. Myślałem, że umarł, ale on jest wszędzie. Nieważne, ile razy się go zabije, jest wszędzie.

(Grimm, Of Mouse and Man)

Wykorzystanie alegorii zwierzęcych przy przedstawianiu kolejnych historii pozwala ukazać określone typy ludzi i relacji między nimi. Przywodzi to na myśl nie tylko baśnie, ale i dydaktyczną bajkę zwierzęcą. Paraludzie ukazują swoje wewnętrzne zwierzęce oblicze pod wpływem emocji. Powiązanie tych okoliczności, faktu, że w serialu przestępcy zawsze okazują się hybrydami, i wiedzy na temat symboliki zwierzęcia w psychoanalizie [por. np. Bettelheim 2010: 126-129] pozwala zinterpretować owo uwidacznianie się zwierzęcości jako dochodzenie do głosu id - popędów, które są źródłem życiowej energii, ale i zachowań destrukcyjnych. Serialowa hybryda jest więc metaforą człowieka, który nie jest w stanie się kontrolować i żyje w zgodzie z zasadą przyjemności, przez co popełnia zbrodnie względem odgórnego porządku. W ten sposób opowieść podsuwa uproszczoną (ale stabilizującą i uspokajającą) odpowiedź na pytanie o przyczyny istnienia zła. Jednocześnie ukazuje nieobecną w tradycyjnej baśni ambiwalencję charakterów i powody, dla których pewni bohaterowie stają się źli. Poskromienie wewnętrznego zwierzęcia jest możliwe, ale wymaga świadomego wysiłku (jeden z bohaterów ćwiczy w tym celu pilates, bierze leki i gra na wiolonczeli). Diagnoza dotycząca konieczności zintegrowania superego, ego i id w celu osiągnięcia równowagi życiowej współgra tak z sensami tradycyjnych 
baśni, jak i z wiedzą psychologiczną. Przykładem udanej indywiduacji są losy głównego bohatera, który po odkryciu przynależności do pewnej grupy zyskuje świadomość tego, skąd się wywodzi, zaczyna rozumieć sposób funkcjonowania świata i swoją rolę. W baśniach drogę do tego rodzaju świadomej aktywności pokonuje najczęściej chłopiec [por. Peju 2008]. Otwarciem w tym zakresie jest wprowadzenie do Once upon a time protagonistki kobiety.

\section{Once upon a time, czyli kobieta postanawia wziąć życie w swoje ręce}

Once upon a time wykorzystuje typowe dla fantasy podwojenie światów. Równolegle otrzymujemy skompilowaną i poszerzoną o nowe elementy opowieść baśniową oraz historię współczesną o „drugim życiu” baśniowych bohaterów. Powodem rozwarstwienia światów jest klątwa, którą Zła Królowa rzuciła na baśniową krainę, pozbawiając wszystkie historie happy endów i kreując „świat bez magii” - współczesność.

Według Grzegorza Jankowicza „przyglądając się baśniom z perspektywy historycznej i kulturowej, łatwo dostrzec powinowactwa między świadomością społeczną danej epoki a obrazem kobiecości, który znajdujemy w spisanych podówczas opowieściach" [Jankowicz 2011]. Pierre Peju, interpretując występujące w tradycyjnych baśniach postaci kobiet, zwraca uwagę na szczególny potencjał dziewczynek jako istot aktywnych i wolnych, podkreśla jednak, że duża część bohaterek, dorastając, zostaje wciągnięta w tryby patriarchalnej maszyny [Peju 2008]. Jako kobiety są „odnajdywane”, „uwalniane”, „oddawane jako nagroda bohaterowi”, a więc sprowadzane do rangi przedmiotu, czekającego w uśpieniu, aż ktoś zmusi je do powrotu do rzeczywistości (Bettelheim mówi tu o dojrzewaniu do aktywności seksualnej [Bettelheim 2010: 351-353 i in.], Pinkola Estes o śpiewaniu nad kośćmi, szukaniu łączności z archetypiczną dziką kobietą [Pinkola Estes 2001]).

Ucieczka od „typowego” kobiecego losu jest w baśniach możliwa, ale ma konsekwencje. Dobrze wizualizują je fotografie Cindy Sherman, artystki tworzącej zdjęcia dobrze wpisujące się w teorię François So- 
ulages’a, który definiuje istotę fotografii jako „to, co zostało odegrane” [Soulages 2007]. Jej twórczość to nie tyle pojedyncze obrazy, ile narracja (storytelling) o różnych kulturowych mitach na temat kobiety [Galenson 2011]. Mniej znany cykl zdjęć pt. Fairy Tales ukazuje aktywną kobietę baśniową, która wyłamała się spod brzemienia kultury patriarchalnej i poniosła konsekwencje w postaci deformacji ciała, upodobnienia się do zwierzęcia, zmaterializowania się tkwiącego w niej abiektu. Trudno interpretować to tylko jako karę za nieposłuszeństwo. Tego rodzaju przemiana oznacza także wyzwolenie wewnętrznej istoty skrępowanej nakazami kultury fallocentrycznej, akceptację tego, co może przerażające, ale naturalne, afirmację kobiecości. Laura Mulvey z kolei widzi w baśniowych zdjęciach Sherman „leksykon lęków [męskich] związanych z kobietą [wiedźmą, kobietą kastrującą itd.]" [Szumlewicz 2004]. Zdjęcie przedstawiające Czerwonego Kapturka interpretuje w następujący sposób:

Czerwony Kapturek na Untitled nr 189 ma zamiast twarzy wydłużony pysk, przypominający wilka. Dziewczynka tak by wyglądała, gdyby nie otrzymała od myśliwego lekcji, że nawet w krainie wyobraźni tylko mężczyzna ma prawo do aktywnego działania [Szumlewicz 2004].

Bierna kobieta z baśni i podejmująca aktywność baśniowa kobieta Sherman to wizerunki znajdujące kontynuację w popkulturze, obrazujące opisywaną przez badaczki tej kultury sprzeczność w komunikatach obecnie kierowanych do kobiet. Zgodnie z tego typu przekazami kobieta powinna być zarazem osobą realizującą się zawodowo i niezależną oraz dobrą matką, żoną, przedmiotem pożądania dla mężczyzny, kochanką o perfekcyjnym wyglądzie [Zierkiewicz, Kowalczyk (red.) 2002]. Zwłaszcza ostatnią kwestię - popkulturowy terror piękna ${ }^{1}$ - często podejmuje się w przeróbkach baśni. Pragnienie bycia piękną i wiecznie młodą (interpretowane jako przejaw próżności lub sposób na niezależność w świecie mężczyzn) popycha kobiety do popełniania zbrodni - w tym wysysania życia z młodych mężczyzn i kobiet. W tym glądasz”.

Termin Naomi Wolf; daje się sprowadzić do maksymy „jesteś, bo wy- 
motywie znajduje wyraz tradycyjne przekonanie, że zjedzenie cudzego ciała (serca, wątroby) pozwala przejąć atrybuty ofiary [Bettelheim 1989]. Utopijność wiary w możliwość zachowania urody i młodości zostaje jednak każdorazowo zdemaskowana - ciało zawsze dopada kobietę (przykładem finał Królewny Śnieżki i Łowcy, Królewny Śnieżki, epizod kobiety-pajęczycy i wiedźmy z serialu Grimm).

Bardziej innowacyjny w zakresie konstrukcji kobiecości jest Once upon a time. W warstwie historii baśniowych następuje zmiana w stosunku do tradycyjnych opowieści - panuje tu względne równouprawnienie. Śnieżka jest wcieleniem Robin Hooda, Księcia ratuje co najmniej tyle razy, ile on ją. Podobną wolę działania ma Kopciuszek, Piękna, Zła Królowa. Klasycznym obrazem jest Czerwony Kapturek, dzika kobieta, która raz w miesiącu przybiera postać krwiożerczego wilka ${ }^{2}$. W serialowej współczesności proces feminizacji idzie jeszcze dalej i przekroczony zostaje zupełnie obraz baśniowo-popkulturowej kobiety jako biernie czekającej na uczucie mężczyzny. Mężczyzn za to dotyka tu kryzys, o którym w odniesieniu do współczesności pisze Zbyszko Melosik [Melosik 2006]. David (Książę) okazuje się tchórzem, dziennikarz (lusterko królowej i dżin z lampy) stale daje się wykorzystywać, szeryf (myśliwy) zostaje zamordowany, gdy decyduje się na działanie. Aktywny wydaje się właściciel miasta, wcielenie karła z baśni Titelitury. Nie jest on jednak typowym reprezentantem świata mężczyzn. Początkowo był wrzeciennikiem, a więc zajmował się czynnością kobiecą, po czym stał się czymś w rodzaju wiedźmy.

Once upon a time jest więc przede wszystkim opowieścią o kobietach, opartą na dwóch antagonizmach. Pierwszy odsyła do baśni - Królowa chce zemścić się na Śnieżce. Co ważne, powodem nienawiści nie jest, jak u braci Grimm, próżność Królowej, ale to, że Śnieżka ją skrzywdziła. Ważniejszy okazuje się jednak drugi konflikt - walka dwóch samotnych kobiet o dziecko. Zestawienie złej królowej i baśniowej wybawicielki jest oczywistym zabiegiem przywołującym archetyp walki dobra ze złem. Z drugiej strony kobiety walczą nie o mężczyznę albo

2 Por. uwagi na temat tego motywu w literaturze przedmiotu i prozie fabularnej, np. Pinkola Estes 2001; Carter 2000. 
dobro świata, ale o dziecko. Taki układ daje się zinterpretować na dwa sposoby: $\mathrm{z}$ jednej strony możemy $\mathrm{w}$ tym miejscu mówić o metaforze ambiwalentnej relacji dziecka względem matki, z drugiej - i to już wkład współczesności - matki względem dziecka. Zgodnie z teorią Melanie Klein dziecko, aby poradzić sobie ze sprzecznymi emocjami, rozszczepia postać matki na dwa obrazy - dobrej i złej, matki i macochy [Segal 2005]. Ze strony kobiety wyglądałoby to tak: podwojenie postaci matki obrazuje dwie funkcje rodzica - macocha (Regina) to władza rodzicielska, opieka i odpowiedzialność, matka (Emma) - czułość i miłość. Ostateczna walka kobiety o bycie matką jest paralelna wobec walki księcia o królewnę, macierzyństwo jest świadomym wyborem. Dziecko okazuje się ważniejsze niż wolność i brak zobowiązań, które czynity z Emmy baśniową dziewczynkę w rozumieniu Peju [Peju 2008]. Zgoda na przyjęcie funkcji macochy - wzięcie odpowiedzialności za dziecko - prowadzi do dojrzałości ${ }^{3}$. Jak wspomina Danuta Ulicka, to fantasy wykreowała „»self-made woman «: [kobietę] samodzielną, odważną, przedsiębiorczą, przede wszystkim zaś mądrą" [Ulicka 1994: 178]. Baśń przypomina, że do bycia taką kobietą i bycia matką się dorasta.

\section{Storytelling w kulturze audiowizualnej}

Mats Rehnman zapytany o istotę storytellingu odpowiedział:

Storytelling jest starą formą komunikacji, starszą niż literatura czy teatr, leżącą u ich źródeł. (...) story - to seria mentalnych obrazów zorganizowanych w znaczący wzór. Storytelling - to rozmaite formy przekazywania opowieści [Rehnman 2011].

Storytelling jest przy tym metodą ,stawiania czoła rzeczywistym niebezpieczeństwom. Pozwala oswoić lęki, pogodzić się z ograniczeniami, którym podlegamy, a także z nieszczęściami, takimi jak strata czy śmierć” [Tamże]. Polega na improwizacji, snuciu nowych opowieści

3 Te sensy oddaje także etymologia imion bohaterek - Emma 'pełna, kompletna', Regina 'królowa, władczyni'. 
na kanwie własnych doświadczeń oraz znanych motywów i fabuł zgodnie z zasadą „każda historia zmienia się w zależności od tego, kto słucha” [Tamże]. Korzyść z modyfikowania starych opowieści podkreślają też Agata Araszkiewicz i Katarzyna Bratkowska: „powinnyśmy przetwarzać baśnie na potrzeby swoje i swoich córek. Wysysając $\mathrm{z}$ nich to, co nas karmi, nie to, co nas truje" [Araszkiewicz, Bratkowska 2005]. W kulturze współczesnej, w której Walter Ong widzi symptomy wtórnej oralności [Ong 1992], Mizrach mówi o telepiśmienności [za: Żydek-Bednarczuk 2003], a słowo coraz częściej wiąże się z obrazem (casus billboardów, reklam, komiksów, poezji wizualnej), funkcje storytellingu przejmują, jak się wydaje, formy audiowizualne o charakterze narracyjnym: filmy, a w większym stopniu seriale. Michał R. Wiśniewski w rozmowie z Jasiem Kapelą określił seriale jako „jedyne wspólne dobro kulturowe” [Wiśniewski 2011: 80]. Serialowe opowieści bazujące na baśniach są o tyle bliskie idei tradycyjnego storytellin$g u$, że przekazują historie pierwotnie obarczone istotnym znaczeniem i stanowią opowieść otwartą, którą - w odpowiedzi na poziom zainteresowania - można snuć przez sezon lub osiem sezonów. Trudno wymagać od nich wpływu na rozwój widzów analogicznego do wpływu baśni na rozwój słuchaczy, ale oferują one nadal rodzaj przeżycia zastępczego i w pewnym stopniu stanowią lustro współczesności. Przy tym wprowadzają perspektywę uniwersalną, która pozwala nadać sens temu, co irracjonalne, przez sprowadzenie niezrozumiałych sytuacji, emocji, postaw do wzorów archetypicznych. Jak wspomina Monika Sznajderman, „potrzeba cudu i obecność mitu wydają się (...) niezbywalną cechą każdej epoki w mniej lub bardziej jawnej formie" [Sznajderman: 96]. Współczesne baśnie, choć w dużym stopniu oddalają się od pierwowzorów, mogą nadal dostarczać Cudowności, pozwalając jednocześnie tropić Tajemnice, które wciąż w dużej mierze dotyczą życia psychicznego. O aktualności baśniowych i fantastycznych wątków obecnych w popkulturze pisał Caillois:

Wyrażają one najwyższy stopień napięcia pomiędzy tym, co człowiek może, a tym, co by chciał móc (...). Wszystkie te rojenia fantazji, z pozoru najswobodniejsze, ukrywają jednak, pod różnokształtną grą symboli, tęsknoty i obawy, które istnieją tak długo, jak człowiek istnieje, i zmienia- 
ją się wraz ze zmianami, jakie wnosi on do swojego losu. Co do tej części losu, która pozostać musi niezmienna, marzenia i lęki też trwają uparcie, przez wieki takie same [Caillois 1967: 64-65].

Ważną funkcją serialowego storytellingu wydaje się przy tym organizowanie ludzi we wspólnoty. Właściwe dla popkultury mieszanie stylów i konwencji gatunkowych, łączenie elementów baśni, literatury, mitów i funkcjonujących już w popkulturze przeróbek, odświeżenie sposobu pokazywania tego, co niby dobrze znane, sprawia, że opowieść wciąga. „Nowa telewizja polega na tworzeniu programów, które mają być dyskutowane, a żeby to osiągnąć, muszą być intrygujące i rzucać wyzwania, muszą dostarczać widzom zagadek i tematów do dyskusji" [Jenkins 2011: 35]. W ten sposób widzowie, wchodząc w może nietrwałe, ale jednak aktywne i angażujące się w dyskusję nad kulturą wspólnoty, tworzą to, co Pierre Levy nazywa inteligencją kolektywną [Jenkins 2001: 34]. Nie jest to wartość specyficzna dla seriali baśniowych. Obecność baśniowego fundamentu wprowadza jednak, także w tym aspekcie, potencjalny naddatek poznawczy - ten, kto chce pełniej interpretować serialowe pomysły i czerpać rozrywkę z przewidywania sposobów łączenia tego, co baśniowe, z tym, co współczesne, musi znać baśnie, mity, legendy lub poznać je równolegle. Co więcej, i to jest już rzeczywista korzyść - aktualizacje opowieści uwypuklają istotne miejsca znanych fabuł i niejako „przy okazji” zapoznają z fragmentami różnych, w tym klasycznych już, interpretacji baśni (Bettelheim, Peju, Seifert, Pinkola Estes, Carter itd.).

\section{Bibliografia}

Araszkiewicz A., Bratkowska K. [2005], Po co kobietom baśnie?, http://www. wysokieobcasy.pl/wysokie-obcasy/1,96856,288500.html?as=2 [dostęp: 14.08.12].

Bettelheim B. [1989], Rany symboliczne. Rytuały inicjacji i zazdrość męska, Danek D. (przeł.), Czytelnik, Warszawa.

Bettelheim B. [2010], Cudowne i pożyteczne. O znaczeniach i wartościach baśni, Danek D. (przeł.), Wyd. W.A.B., Warszawa. 
Caillois R. [1967], Od baśni do „science-fiction”, [w:] Odpowiedzialność i styl: eseje, Błoński J. i in. (przeł.), PIW, Warszawa, 31-65.

Carter A. [2000], Towarzystwo wilków, [w:] Czarna Wenus. Opowiadania, Ambros A. (przeł.), Czytelnik, Warszawa, 206-221.

FranczakJ. [2011],Porzadkowanie chaosu,http://tygodnik.onet.pl/43,0,58934, porzadkowanie_chaosu,artykul.html [dostęp: 13.08.12].

Galenson D. [2011], The Unique Value of Cindy Sherman, http://www.huffingtonpost.com/david-galenson/the-unique-value-of-cindy_b_871803. html [dostęp: 10.08.12].

Jankowicz G. [2011], Emancypacja Śnieżki, http://tygodnik.onet. pl/43,0,58933,emancypacja_sniezki,artykul.html [dostęp: 14.08.12].

Jenkins H. [2011], Seriale tworzą nowe wspólnoty (rozmowa z Sz. Grelą), [w:] Seriale. Przewodnik Krytyki Politycznej, Wyd. Krytyki Politycznej, Warszawa, 32-46.

Klimek K. [2011], Baśnie księżniczki popkultury, „Film”, nr 72, http://www. dwutygodnik.com/artykul/2967-basnie-ksiezniczki-popkultury.html [dostęp: 14.08.12].

Majkowski T. Z. [2011], Nowe przygody Królewny, http://tygodnik.onet.pl/ 43,0,58931,nowe_przygody_krolewny,artykul.html [dostęp: 12.08.12].

Melosik Z. [2006], Kryzys męskości w kulturze wspótczesnej, Impuls, Kraków.

Miller K., Cichocka T. [2009], Bajki rozebrane: jak odnaleźć się w swojej baśni, JK - Feeria, Łódź.

Ong W. [1992], Wtórna oralność, [w:] Oralność i piśmienność. Stowo poddane technologii, Japola J. (przeł.), Redakcja Wydawnictw KUL, Lublin, $179-186$.

Peju P. [2008], Dziewczynka w baśniowym lesie. O poetykę baśni: w odpowiedzi na interpretacje psychoanalityczne i formalistyczne, Pluta M. (przel.), Sic!, Warszawa.

Pinkola Estes C. [2001], Biegnaca z wilkami. Archetyp dzikiej Kobiety w mitach i legendach, Cioch A. (przeł.), Zysk i S-ka, Poznań.

Sznajderman M. [1994], Teologia pięknych kobiet, [w: Mitologie popularne: szkice $z$ antropologii wspótczesności, Czaja D. (red.), Universitas, Kraków, 195-213.

Szumlewicz K. [2004], Fotografie Cindy Sherman, www.gender.uni.wroc.pl/ index.php?lang=pl\&dzial=artykuly\&k=teksty_online\&p=szumlewicz katarzyna_fotografie_cindy_sherman [dostęp: 10.08.12].

Rehnman M. [2011], Zāwód: gawędziarz, http://tygodnik.onet.pl/43,0, 58935,zawod_gawedziarz,artykul.html [dostęp: 14.08.12]. 
Segal H. [2005], Wprowadzenie do teorii Melanie Klein, Penderecki Ł. (przeł.), Gdańskie Wydawnictwo Psychologiczne, Gdańsk.

Soulages F. [2007], Estetyka fotografii. Strata i zysk, Mytych-Forajter B., Forajter W. (przeł.), Universitas, Kraków.

Ulicka D. [1994], Literatura źle widziana, [w:] Mitologie popularne: szkice $z$ antropologii wspótczesności, Czaja D. (red.), Universitas, Kraków, 167171.

Wiśniewski M.R. [2011], Jedyne wspólne dobro kulturowe (rozmowa z J. Kapelą), [w: ] Seriale. Przewodnik Krytyki Politycznej, Wyd. Krytyki Politycznej, Warszawa, 73-83.

Zierkiewicz E., Kowalczyk I. (red.) [2002], Kobiety w kulturze popularnej, Konsola, Poznań.

Żydek-Bednarczuk U. [2003], Tekst w Internecie i jego wyznaczniki, http:// uranos.cto.us.edu.pl/ dialog/archiwum/zydek-bednarczuk.pdf [dostęp: 12.08.12].

\section{Źródła - seriale i filmy}

Grimm (2011), reż. M. Buckland, N. Barba.

Królewna Śnieżka (2012), reż. T. Singh.

Królewna Śnieżka i Łowca (2012), reż. R. Sanders.

Once upon a time (2011), reż. M. Mylod, D. Solomon. 